\title{
Evaluation of Meat Consumption Pattern and Meat Quality in North Indian Cities
}

\author{
Suman Talukder ${ }^{1 *}$, Sanjod Kumar Mendiratta ${ }^{1}$, Rajiv Ranjan Kumar ${ }^{1}$, Arvind Soni ${ }^{2}$ and Dwaipayan Bardhan ${ }^{3}$ \\ ${ }^{1}$ Division of Livestock Products Technology, ICAR-IVRI, Izatnagar, Bareilly, Uttar Pradesh, INDIA \\ ${ }^{2}$ Division of Livestock Products Technology, ICAR-CSWRI, Malpura, Tonk, Rajasthan, INDIA \\ ${ }^{3}$ Division of Livestock Economics Statistics and Information Technology, ICAR-IVRI, Izatnagar, Bareilly, Uttar Pradesh, INDIA
}

*Corresponding author: S Talukder; E-Mail:drttalukder@gmail.com

Received: 15 Mar., 2020

Revised: 24 April, 2020

Accepted: 10 May, 2020

\begin{abstract}
A survey was conducted in north Indian cities (Ghaziabad, Noida, Gurugram, Delhi, Lucknow and Bareilly) with an aim to evaluate meat consumption pattern and meat products quality. Retailers from 15 randomly chosen shops, viz., Shop-A, B, C...O and 403 consumers visiting those shops were interviewed. Sample meat products from 10 shops were collected and quality evaluated. Among retailers, $73.33 \%$ told meat Kabab (chicken and chevon), is the most sold out product. As per 50.37\% $\& 34.24 \%$ consumers chicken and goat meat was $1^{\text {st }}$ and $2^{\text {nd }}$ preference of meat species respectively, $53.46 \%$ of consumers preferred "taste" as their first criteria of meat products purchase, $62.85 \%$ consumers preferred convenience meat products as compared to traditional counterparts, highest percentage of (43.42\%) consumers chosen seekh kabab (chicken and chevon) as their first preference of product. Evaluation of market products quality revealed that, maximum and minimum protein percentage in Shop-A, Chicken Kabab (16.73\%) and Shop-C, Chicken Kabab (5.32\%) respectively. Cholesterol content found maximum and minimum amount in Mutton Kabab from Shop-J (60.72 mg/100g) and Chicken Sausages from Shop-N (33.54 mg/100g) respectively. Calcium content found highest in Chicken Kabab from Shop-C (1.63\%). Highest Total Plate Count (TPC) detected in chicken Kabab from Shop-D (5.41 log $10 \mathrm{cfu} / \mathrm{g})$.
\end{abstract}

Keywords: NCR cities, Lucknow, Bareilly, Meat consumer, Meat products.

Food of animal origin in relation to protein contents are at the top of the food chain (Chemnitz and Becheva, 2014) and among that meat occupies the principal position. Meat is most widely used important food commodity of animal origin food. It contains quality protein, palatability enhancing fat, energy providing carbohydrates, vitamins as well as essential fatty acids and micronutrients which make it a balanced diet for most of the people (Sharma et al., 2018). It constitutes the major portion of Indian nonvegetarian meal and always signifies as symbol of prestige but its availability here in our country is only about $15 \mathrm{~g} /$ person/day against the ICMR recommendation of $30 \mathrm{~g} / \mathrm{person} /$ day (Islam et al., 2016). The traditions and culture influences meat consumption to a great extent in India (Devi et al., 2014). The bio-availability of meat proteins is high with (Net protein utilization value around
0.75 as against $0.5-0.6$ for plant proteins) balanced amino acid profile having higher digestibility (Sharma, 2003). Increase in meat production and its demand is expected to take place in near future mainly in developing countries like India.

Meat consumption behavior is the pivotal factor for the development of livestock sector based economy. In gross, consumer's behavior in relation to choosing a food item indicates the process and activities that they follow when they search, select and purchase any food item to satisfy their needs and decisions. Various external factors such as culture, sub culture, social class, reference groups, family decisions and certain situational determinants

How to cite this article: Talukder, S., Mendiratta, S.K., Kumar, R.R., Soni, A. and Bardhan, D. (2020). Evaluation of meat consumption pattern and meat quality in North Indian cities. J. Anim. Res., 10(3): 365-373. Source of Support: None; Conflict of Interest: None 
also influence the consumer's purchase decisions. Meat consumption behavior falls within these lines and varies with the societal set up in which the consumers are operating (Raju and Suryanarayana, 2005). Till date the culture, traditions, customs, taboos and finally the quality of the available meat products influences the consumption pattern of meat and meat products, in all the strata of Indian society. Nutritional, functional and hygienic attributes of available market meat products determines its acceptability. Therefore, maintaining the optimum quality of meat products should always be the priority of both processors and retailers engaged in meat business. Following of good manufacturing, handling and packaging practices, maintenance of cold chain are the issues influence the meat products quality at any point in supply chain.

Structured information of meat consumption pattern and existing market meat products quality of a particular area is very much necessary to develop the future strategies for face lifting of meat processing industries in that area because in the present world, supply of quality food to the consumer in its safest form is the biggest challenge to the food processors (Talukder and Mendiratta, 2017). Furthermore the basic database can help to ensure the food safety of consumer and can deal the future problems related to meat and meat products as well. In India, a significant portion of meat consumer belongs to the major northern Indian cities viz., NCR (Delhi, Ghaziabad, NOIDA and Gurugram), Lucknow and Bareilly. Generation of data base of meat and meat product consumption pattern in this vast area and the evaluation of existing quality of the market meat products will be very much useful in planning and development of future strategies of meat business and will assure the food safety of the consumers efficiently.

\section{MATERIALS AND METHODS}

\section{Study site and timing}

The present study was undertaken in 6 major cities in northern India viz., Ghaziabad, NOIDA, Gurugram, Delhi, Lucknow and Bareilly. From each city at least 2-3 retail meat shops, engaged in selling of fresh meat and convenience/ traditional meat products, were identified randomly (Table 1). The survey was carried out during the month of September, 2017 to April, 2018.

\section{Selection of respondents}

A random sampling procedure was used. Total 15 retail meat shops (Table 1) were selected and their owners along

Table 1: Shops of meat products and types of visiting consumers

\begin{tabular}{|c|c|c|c|c|c|c|c|}
\hline \multirow{2}{*}{ SI. No. } & \multirow{2}{*}{ Retail Shop } & & \multirow{2}{*}{ Sampling } & \multirow{2}{*}{ Retailer No } & \multirow{2}{*}{$\begin{array}{l}\text { Number of } \\
\text { Consumer }\end{array}$} & \multicolumn{2}{|c|}{ Gender } \\
\hline & & & & & & Male & Female \\
\hline 1 & \multirow{2}{*}{ Ghaziabad } & Shop-A & Yes & 1 & 41 & 27 & 14 \\
\hline 2 & & Shop-B & - & 1 & 30 & 18 & 12 \\
\hline 3 & \multirow{5}{*}{ NOIDA } & Shop-C & Yes & 1 & 20 & 11 & 9 \\
\hline 4 & & Shop-D & Yes & 1 & 20 & 13 & 7 \\
\hline 5 & & Shop-E & - & 1 & 20 & 12 & 8 \\
\hline 6 & & Shop-F & Yes & 1 & 20 & 13 & 7 \\
\hline 7 & & Shop-G & - & 1 & 17 & 10 & 7 \\
\hline 8 & \multirow{2}{*}{ Gurugram } & Shop-H & Yes & 1 & 35 & 30 & 5 \\
\hline 9 & & Shop-I & Yes & 1 & 30 & 22 & 8 \\
\hline 10 & \multirow{2}{*}{ Delhi } & Shop-J & Yes & 1 & 30 & 21 & 9 \\
\hline 11 & & Shop-K & - & 1 & 30 & 20 & 10 \\
\hline 12 & \multirow{2}{*}{ Lucknow } & Shop-L & Yes & 1 & 30 & 26 & 4 \\
\hline 13 & & Shop-M & Yes & 1 & 30 & 22 & 8 \\
\hline 14 & \multirow{2}{*}{ Bareilly } & Shop-N & Yes & 1 & 25 & 18 & 7 \\
\hline 15 & & Shop-O & - & 1 & 25 & 16 & 9 \\
\hline Total & & & & 15 & 403 & 279 & 124 \\
\hline
\end{tabular}


with 403 consumers both male and female, visiting those shops were interviewed at the shops.

\section{Data collection}

A well structured, bilingual (Hindi \& English) questionnaire used separately for retailers and consumers. The retailers answered basic information viz., amount and species of meat sold per week, most preferred meat products of consumer etc. Whereas, consumer answered the basic informative questions, viz., preference of meat species and products, frequency and quantity of meat and meat products consumption per month, their preference of feature in meat products during purchase, preference for place of purchasing, preference for traditional or convenience meat products, most frequently purchased convenience product and its brand. The personal opinion of retail shop owners and the consumers about the present trends of meat consumption behaviour in the society, other than included in questionnaire were also tabulated and analyzed.

\section{Quality evaluation of samples}

The proximate composition of collected samples was determined as per AOAC (1995). Calorific values of the samples were determined by Gallenkamp and Ballistic Bomb Calorimeter (Haque and Murali, 1999). Total dietary fibre (TDF), was determined by slight modification of an enzymatic method (Furda, 1981). Thiobarbituric acid reactive substances (TBARS) value of samples was determined by the distillation method (Tarladgis et al., 1960). The Free Fatty Acid (FFA) content was determined as per Koniecko (1979). The microbiological parameter (Total Plate Count, Psychrophilic count and coliform count) was determined as per APHA (1984). The mineral profiling of samples was done by following the method of Irshad (2014).

\section{STATISTICAL ANALYSIS}

The collected primary data obtained through survey forms were recorded. Suitable statistical tool used for the analysis of data. The responses were grouped together and presented in the form of frequencies and percentages.

\section{RESULTS AND DISCUSSION}

The number of consumer from individual shop varied between 17-41 depending on their availability. The variability in the number of male and female consumers, encountered during survey was might be due to less preference to meat consumption by female consumers as compared to vegetarian diet, social stratification, environmental reason etc. The reason for this might be linked to the idea that some foods are seen as masculine and some are feminine. Traditionally, the meat consumption is described as more masculine while the consumption of vegetables and fruits is more feminine (Prattala et al., 2006)

\section{Selling pattern of retailer}

The data related to selling pattern of meat and meat products provided by the retailer is presented in Table 2 . The data shows, $60 \%$ of the retailer are graduate and $33.33 \%$ are post graduate degree holders, which indicate that, the present meat business is handled by only educated class of retailers, which ensures proper up keeping of good quality products in proper storage conditions and supply of quality products to the consumers.

Table 2: Opinion of retailer regarding selling pattern $(n=15)$

\begin{tabular}{clll}
\hline $\begin{array}{c}\text { Sl. } \\
\text { No. }\end{array}$ & Variables & Category & $\begin{array}{l}\text { Frequency } \\
(\%)\end{array}$ \\
\hline 1 & Educational qualification of & $\leq 10^{\text {th }}$ & 0 \\
& retailer & $10^{\text {th }}-12^{\text {th }}$ & 6.66 \\
& & Graduate & 60 \\
& & Post graduate & 33.33 \\
\hline 2 & Species of meat sell & Chicken & 46.67 \\
& & Chevon/Mutton & 26.67 \\
& & Fish & 13.33 \\
& & Pork & 6.67 \\
& & Other & 6.67 \\
\hline 3 & Quantity of meat sell $(\mathrm{kg}) /$ & $\leq 40 \mathrm{~kg}$ & 6.67 \\
& week & $40-60$ & 46.67 \\
& & $60-80$ & 26.67 \\
& & $80-100$ & 6.67 \\
& & $\geq 100$ & 13.33 \\
\hline 4 & Quantity of product sell & $\leq 10 \mathrm{~kg}$ & 13.33 \\
& & $10-20$ & 6.67 \\
& & $20-30$ & 6.67 \\
& & $30-40$ & 20 \\
& & $40-50$ & 40 \\
& & $\geq 50$ & 13.33 \\
\hline & & & \\
& & &
\end{tabular}


Talukder et al.

\begin{tabular}{|c|c|c|c|}
\hline \multirow[t]{4}{*}{5} & Most sold out product & $\begin{array}{l}\text { Tandoor } \\
\text { product }\end{array}$ & 0 \\
\hline & & Kabab & 73.33 \\
\hline & & $\begin{array}{l}\text { Patties/nuggets/ } \\
\text { balls/salami }\end{array}$ & 20 \\
\hline & & Other & 6.66 \\
\hline \multirow[t]{5}{*}{6} & $\begin{array}{l}\text { Pattern of change in meat } \\
\text { business in last five years }\end{array}$ & $\begin{array}{l}\text { Increase in } \\
\text { fresh meat sell }\end{array}$ & 13.33 \\
\hline & & $\begin{array}{l}\text { Decrease in } \\
\text { fresh meat sell }\end{array}$ & 0 \\
\hline & & $\begin{array}{l}\text { Increase in } \\
\text { product sell }\end{array}$ & 80.00 \\
\hline & & $\begin{array}{l}\text { Decrease in } \\
\text { product sell }\end{array}$ & 0 \\
\hline & & $\begin{array}{l}\text { No change in } \\
\text { selling pattern }\end{array}$ & 6.67 \\
\hline
\end{tabular}

According to $46.67 \%$ retailer chicken is the most sold out meat species. Whereas $26.67 \%$ retailer told chevon/ mutton is most sold species. Easy availability, lower price of chicken as compared to other ruminant meat might be the reason why it is being preferred by the consumers most. According to Devi et al. (2014) chicken is India's preferred non vegetarian protein source. The health benefits of fish meat is the reason of preference by the consumers, told by $13.33 \%$ retailer, similar view has been given by Mohanty (2011). Retailer (46.67\%) told about selling of $40-60 \mathrm{~kg}$ fresh meat per week. There is very less processing of meat in India, hardly $1 \%$ of the total meat produced is used for processing remaining meat sold in fresh or frozen form (Guleria et al., 2015). In India, meat produced for the domestic market is sold as hot meat (Ranjhan, 2004).

According to $40 \%$ retailer, they sells $40-50 \mathrm{~kg}$ meat products per week, whereas, $13.33 \%$ retailer sells of $\geq 50$ $\mathrm{kg} / \mathrm{week}$. The increasing demands of ready to eat meat products among consumer might be due to preference of convenience meat products. Changes in socioeconomic status, increasing number of women entering in the workforce are fuelling high demand for ready to eat type of meat products, has also been described by Gadekar and Shinde (2011). As per $73.33 \%$ of retailer Kabab (chicken/ chevon), was the most preferred processed meat, might be due to its unique, charcoal grille taste and flavor, readily availability, economic nature and finally its enriched nutritional character. Similarly, Bhat et al. (2013) have also described Kababs as one of the most popular convenience ready to eat meat products which are available in food outlets worldwide. As per $20 \%$ of retailer emulsion based meat products viz., patties/nuggets/balls/salami were most preferred by consumer. Similarly Devatkal et al. (2014) described the popularity of emulsion based meat products, like burger patties, balls (kofta), Kebabs, frankfurter type sausages and nuggets, in India. Regarding the pattern of change in meat business, the $80 \%$ retailer agreed about the increase in selling of products since last five years. Increasing production and processing, application of newer technologies for the production, increasing demands for convenience RTE meat products of today's consumers are may be the possible reasons behind the increasing business of meat and meat products. Similar observation has also been quoted by Devi et al. (2014). According to Food and Agriculture Organization of the United Nations (FAO, Statistics, 2012) forecasts, future consumption of animalbased products in developing countries is projected to increase by $29-35 \%$ in 2030 and $37 \%$ in 2050 , which can be compared to an average of $48 \%$ in industrial countries.

\section{Problems in meat business and consumer's expectations}

During survey, the problems faced by retailer in meat business and consumer's expectation to them were also addressed and presented in Table 3. In response $86.67 \%$ retailer told about the gradually increasing competition in market of ready to cook (RTC) and ready to eat meat (RTE) meat products. Changing lifestyle, shortage of time to cock, convenience in life of the urban population might be the reason why the convenience RTE \& RTC products are getting popularity day by day. Similar findings were observed by Vijayabaskar and Sundaram (2012) in their study of market for Ready-to-eat/cook products in Southern India. 93.33\% retailer told about the problems of existing myth about frozen meat and meat products in market. According them consumer believe that, frozen meat and meat products are not of good quality, because they are afraid of the condition of its preservation, which drastically reduce the sell of readily available frozen meat and products and affect the business as well. Similar observation has been noticed by Tzimitra-Kalogianni (1998). It has been observed that there is existing social pressure against non vegetarianism (6.67\% response).

In present study, $93.33 \%$ consumers prefer convenience meat products. As a result, there is a growing demand 
for convenient, packaged processed meat products (ICFA, 2016). As per retailers' opinion, 100\% consumers demands both tasty and healthy meat products. The heath consciousness of taste loving consumers is might be the reason behind that.

Table 3: Problems faced by retailer in meat business and consumer's expectation to them $(n=15)$

\begin{tabular}{|c|c|c|}
\hline $\begin{array}{l}\text { SI. } \\
\text { No. }\end{array}$ & Variables & $\begin{array}{l}\text { Frequency } \\
(\%)\end{array}$ \\
\hline \multirow[t]{5}{*}{1} & Problems in meat business & \\
\hline & » Increased competition in market & 86.67 \\
\hline & $\begin{array}{l}\text { Myth about the quality of frozen meat and } \\
\text { products }\end{array}$ & 93.33 \\
\hline & » Social pressure against non vegetarianism & 6.67 \\
\hline & $\begin{array}{l}\text { Less supply of quality raw material as } \\
\text { compared to demand }\end{array}$ & 26.67 \\
\hline \multirow[t]{5}{*}{2} & Consumer's expectation to retailer & \\
\hline & » Demands for convenience meat products & 93.33 \\
\hline & » Tasty but healthy meat products & 100.00 \\
\hline & " Low fat in meat/product & 86.67 \\
\hline & "Demands for fish and fish products & 80.00 \\
\hline
\end{tabular}

Among retailer, $86.67 \%$ told that the health conscious consumers demands for healthy meat products in relation of low level of fat in them. This may have arisen from the healthy advice from doctor, social medias etc. urging consumers to reduce their intake of fat, particularly saturated fat, in order to avoid obesity, lower the risk of coronary heart disease etc. (Jalal et al., 2015). In the present market demands is there for ready to eat, least spicy and healthy products by health club members, has been admitted by $66.67 \%$ retailer.

\section{Characteristics of meat consumer}

The socio-economic and demographic characteristics of consumer are presented in Table 4. It has been observed that the male member $(69.23 \%)$ of the family are more engaged in purchasing of meat and meat products as compared to female member $(30.76 \%)$. The nature of the family of most $(50.37 \%)$ of the consumer are nuclear type, they consists of 3-4 family members. The number of family which consists of 5-6 members is $32.75 \%$.

When the expenditure for monthly meat consumption is concern, it has been observed that the maximum $40.69 \%$ of the consumer expense ₹ 1000-1500/- per month. Whereas, $26.80 \%$ of the consumer expenses ₹ $1500-2000 /-$ per month. Maximum number $(48.88 \%)$ of consumer takes meat and meat products in dinner, whereas $27.05 \%$ consumer takes it as snacks. It has been observed that $51.61 \%$ of the consumers take meat and meat products 3-4 times a week as an integral part of their meals. The results showed that, grains and vegetables are the $1^{\text {st }}$ choice of food item. According to $46.90 \%$ consumers there is reduction in fresh meat consumption since last two years and $52.85 \%$ consumers agreed with the fact that there is increase in processed meat consumption.

Table 4: Demographic, socio-economic and behavioral characteristic of consumers $(n=403)$

\begin{tabular}{|c|c|c|c|}
\hline $\begin{array}{l}\text { SI. } \\
\text { No. }\end{array}$ & Variables & Category & $\begin{array}{l}\text { Frequency } \\
(\%)\end{array}$ \\
\hline \multirow[t]{2}{*}{1} & \multirow{2}{*}{$\begin{array}{l}\text { Gender of meat } \\
\text { purchaser }\end{array}$} & Male & 69.23 \\
\hline & & Female & 30.76 \\
\hline \multirow[t]{4}{*}{2} & \multirow[t]{4}{*}{ House hold size } & $\leq 2$ & 7.94 \\
\hline & & $3-4$ & 50.37 \\
\hline & & $5-6$ & 32.75 \\
\hline & & $\geq 6$ & 8.93 \\
\hline \multirow[t]{5}{*}{3} & \multirow{5}{*}{$\begin{array}{l}\text { Monthly meat } \\
\text { consumption } \\
\text { expenditure (₹) }\end{array}$} & $\leq 500$ & 3.47 \\
\hline & & $500-1000$ & 17.62 \\
\hline & & $1000-1500$ & 40.69 \\
\hline & & $1500-2000$ & 26.80 \\
\hline & & $\geq 2000$ & 11.41 \\
\hline \multirow[t]{4}{*}{4} & \multirow{4}{*}{$\begin{array}{l}\text { Meat is taken in the } \\
\text { meal }\end{array}$} & Breakfast & 5.21 \\
\hline & & Lunch & 18.86 \\
\hline & & Dinner & 48.88 \\
\hline & & Snacks & 27.05 \\
\hline \multirow[t]{4}{*}{5} & \multirow[t]{4}{*}{ Meat intake per week } & $\leq 2$ & 26.05 \\
\hline & & $3-4$ & 51.61 \\
\hline & & $5-6$ & 14.39 \\
\hline & & Every day & 7.94 \\
\hline \multirow[t]{4}{*}{6} & \multirow{4}{*}{$\begin{array}{l}\text { Position of meat/meat } \\
\text { products in respect to } \\
\text { nutritional priority in } \\
\text { diet }\end{array}$} & Grains/Vegetable & 45.66 \\
\hline & & Milk/Milk products & 35.24 \\
\hline & & $\begin{array}{l}\text { Meat/Meat } \\
\text { products }\end{array}$ & 18.61 \\
\hline & & Other & 0.5 \\
\hline \multirow[t]{3}{*}{7} & \multirow{3}{*}{$\begin{array}{l}\text { In last } 2 \text { years fresh } \\
\text { meat consumption status }\end{array}$} & Increased & 41.44 \\
\hline & & Decreased & 46.90 \\
\hline & & Maintained & 11.66 \\
\hline \multirow[t]{3}{*}{8} & \multirow{3}{*}{$\begin{array}{l}\text { In last } 2 \text { years processed } \\
\text { meat consumption status }\end{array}$} & Increased & 52.85 \\
\hline & & Decreased & 38.71 \\
\hline & & Maintained & 8.44 \\
\hline
\end{tabular}




\section{Meat purchasing behavior}

Meat purchasing behavior of the consumers has been evaluated and presented in Table 5. It has been observed that $50.37 \%$ consumer's $1^{\text {st }}$ preference is chicken meat. Consumption of meat in India is particularly determined by the religions, as there is no religious prohibition attached to poultry meat and it is healthy as well, it is highly accepted (Devi et al., 2014). The $2^{\text {nd }}$ preference of goat $/$ sheep meat is agreed by $34.24 \%$ consumers. The unbeatable taste, flavor and texture of goat and sheep meat might be the reason for the preference.

Table 5: Meat purchasing behavior of consumers $(\mathrm{N}=403)$

\begin{tabular}{|c|c|c|c|}
\hline $\begin{array}{l}\text { Sl. } \\
\text { No. }\end{array}$ & Variables & Category & $\begin{array}{l}\text { Frequency } \\
(\%)\end{array}$ \\
\hline \multirow[t]{5}{*}{1} & \multirow[t]{5}{*}{ Species of meat preferred } & Chicken & 50.37 \\
\hline & & Goat/Sheep & 34.24 \\
\hline & & Fish & 7.94 \\
\hline & & Pork & 4.22 \\
\hline & & Other & 3.23 \\
\hline \multirow[t]{4}{*}{2} & \multirow[t]{4}{*}{ Purchase meat from } & $\begin{array}{l}\text { Traditional } \\
\text { meat shop }\end{array}$ & 41.19 \\
\hline & & $\begin{array}{l}\text { Departmental } \\
\text { store }\end{array}$ & 29.03 \\
\hline & & Road side stall & 24.57 \\
\hline & & Other & 5.21 \\
\hline \multirow[t]{4}{*}{3} & \multirow[t]{4}{*}{$\begin{array}{l}\text { Purchase meat products } \\
\text { from }\end{array}$} & $\begin{array}{l}\text { Traditional } \\
\text { meat shop }\end{array}$ & 33.75 \\
\hline & & $\begin{array}{l}\text { Departmental } \\
\text { store }\end{array}$ & 32.51 \\
\hline & & Road side stall & 20.84 \\
\hline & & Other & 12.90 \\
\hline \multirow[t]{2}{*}{4} & \multirow[t]{2}{*}{ Preferred meat products type } & Traditional & 37.47 \\
\hline & & Convenient & 62.53 \\
\hline \multirow[t]{6}{*}{5} & \multirow{6}{*}{$\begin{array}{l}\text { Most preferred convenient } \\
\text { product/s }\end{array}$} & Kabab/ Tikka & 43.42 \\
\hline & & Nuggets & 18.86 \\
\hline & & Sausages & 14.39 \\
\hline & & Fish products & 7.20 \\
\hline & & Patties & 2.98 \\
\hline & & Salami/Ham & 13.15 \\
\hline \multirow[t]{5}{*}{6} & \multirow[t]{5}{*}{ Product attributes preference } & Taste & 50.12 \\
\hline & & Nutritive value & 30.77 \\
\hline & & Price & 1.49 \\
\hline & & Brand name & 11.41 \\
\hline & & Packaging & 6.20 \\
\hline
\end{tabular}

Among consumer, $41.19 \%$ and $33.75 \%$ told about their preference of place of purchase fresh meat and meat products respectively from traditional meat shop, whereas, only $29.03 \%$ and $32.51 \%$ consumer prefer departmental store for purchase fresh meat and meat products respectively, the probable reasons behind this might be, the lack of awareness of consumers about hygiene and safety. It has been observed that $62.53 \%$ consumer preferred convenience meat products, which might be due to its easy processing, handling.

As most preferred meat products, Kabab has been chosen by $43.42 \%$ consumer. The characteristic traditional flavor and taste of charbroiled kababs is due to combustion of fat that drips on the red hot charcoal (Anjaneyulu et al., 2008) might be the reason behind this.

Survey showed that $50.12 \%$ consumer preferred "taste" as their first criteria to purchase meat products, which might be contributed by various sensory attributes of meat products as taste, texture, aroma, and appearance have distinct and influential effects on acceptability of meat product.

\section{Quality attributes of market meat products}

The proximate composition, calorific value and fat quality attributes of market meat products samples have been evaluated and presented in Table 6. It has been observed that the protein and fat percentage varied from $5.32 \%$ (C-Chicken Kabab) to $16.73 \%$ (A-Chicken Kabab) and 5.74 (N-Chicken Sausages) to 16.95 (I-Chicken Sausages) respectively in different samples. Dietary fiber is an important component to be incorporated in meat products to improve functionality of products, found in maximum amount in C-Chicken Kabab sample (5.08\%). All the meat products samples are found to be with high calorific value, maximum calories found in I-Chicken Sausages (251 $\mathrm{Kcal} / 100 \mathrm{~g})$.

The TBARS and FFA are the two attributes which determines the fat quality in meat products. Higher value of TBARS than the acceptable range (1-2 mg MLD/kg, Malav et al., 2016) has been observed only in one sample F-Chicken Sausages (2.02 mg MLD/kg), in all other market samples the value found under acceptable limit. Whereas, FFA value indicates the breakdown of fat and it found maximum in I-Chicken Sausages sample (1.26\% 
Table 6: Nutritional and fat quality attributes of meat products $(\mathrm{N}=10)$

\begin{tabular}{|c|c|c|c|c|c|c|c|c|c|c|}
\hline Shop/ Product & $\begin{array}{l}\text { Moisture } \\
\text { (\%) }\end{array}$ & $\begin{array}{l}\text { Protein } \\
(\%)\end{array}$ & $\begin{array}{l}\text { Fat } \\
(\%)\end{array}$ & $\begin{array}{l}\text { Ash } \\
(\%)\end{array}$ & $\begin{array}{l}\text { Carbohy- } \\
\text { drate }(\%)\end{array}$ & $\begin{array}{l}\text { Dietary } \\
\text { fiber }(\%)\end{array}$ & $\begin{array}{l}\text { Calorific } \\
\text { value } \\
\text { (Kcal/100g) }\end{array}$ & $\begin{array}{l}\text { TBARS } \\
\text { (mg malonal- } \\
\text { dehyde/Kg) }\end{array}$ & $\begin{array}{l}\text { FFA (\% } \\
\text { oleic acid) }\end{array}$ & $\begin{array}{l}\text { Cholesterol } \\
\text { (mg/100g) }\end{array}$ \\
\hline A. Chicken Kabab & $\begin{array}{l}63.33 \pm \\
1.93\end{array}$ & $\begin{array}{l}16.73 \pm \\
0.26\end{array}$ & $\begin{array}{l}13.62 \pm \\
0.56\end{array}$ & $\begin{array}{l}2.35 \pm \\
0.13\end{array}$ & $\begin{array}{l}3.96 \pm \\
1.55\end{array}$ & $\begin{array}{l}1.52 \pm \\
0.14\end{array}$ & $\begin{array}{l}198.33 \pm \\
4.80\end{array}$ & $1.57 \pm 0.54$ & $\begin{array}{l}0.76 \pm \\
0.03\end{array}$ & $\begin{array}{l}45.33 \pm \\
2.84\end{array}$ \\
\hline C. Chicken Kabab & $\begin{array}{l}64.28 \pm \\
1.54\end{array}$ & $\begin{array}{l}5.32 \pm \\
0.19\end{array}$ & $\begin{array}{l}14.42 \pm \\
0.63\end{array}$ & $\begin{array}{l}2.18 \pm \\
0.06\end{array}$ & $\begin{array}{l}13.79 \pm \\
2.31\end{array}$ & $\begin{array}{l}5.08 \pm \\
0.54\end{array}$ & $211 \pm 3.6$ & $1.91 \pm 0.04$ & $\begin{array}{l}0.76 \pm \\
0.06\end{array}$ & $\begin{array}{l}42.33 \pm \\
2.40\end{array}$ \\
\hline D. Chicken Kabab & $\begin{array}{l}67.80 \pm \\
0.33\end{array}$ & $\begin{array}{l}7.49 \pm \\
0.18\end{array}$ & $\begin{array}{l}13.50 \pm \\
0.76\end{array}$ & $\begin{array}{l}2.05 \pm \\
0.01\end{array}$ & $\begin{array}{l}9.14 \pm \\
0.77\end{array}$ & $\begin{array}{l}3.59 \pm \\
0.73\end{array}$ & $\begin{array}{l}191.33 \pm \\
0.88\end{array}$ & $1.68 \pm 0.30$ & $\begin{array}{l}0.96 \pm \\
0.13\end{array}$ & $\begin{array}{l}57.66 \pm \\
2.90\end{array}$ \\
\hline F. Chicken Sausage & $\begin{array}{l}69.45 \pm \\
0.67\end{array}$ & $\begin{array}{l}12.47 \pm \\
0.73\end{array}$ & $\begin{array}{l}7.51 \pm \\
0.87\end{array}$ & $\begin{array}{l}2.61 \pm \\
0.08\end{array}$ & $\begin{array}{l}7.95 \pm \\
1.39\end{array}$ & $\begin{array}{l}3.48 \pm \\
0.61\end{array}$ & $\begin{array}{l}150.64 \pm \\
2.73\end{array}$ & $2.02 \pm 0.05$ & $\begin{array}{l}0.89 \pm \\
0.02\end{array}$ & $\begin{array}{l}46.67 \pm \\
0.26\end{array}$ \\
\hline H. Chicken Kabab & $\begin{array}{l}63.28 \pm \\
3.22\end{array}$ & $\begin{array}{l}16.60 \pm \\
0.26\end{array}$ & $\begin{array}{l}12.91 \pm \\
0.36\end{array}$ & $\begin{array}{l}2.09 \pm \\
0.15\end{array}$ & $\begin{array}{l}5.11 \pm \\
3.23\end{array}$ & $\begin{array}{l}2.28 \pm \\
0.17\end{array}$ & $\begin{array}{l}199.45 \pm \\
1.13\end{array}$ & $1.60 \pm 0.27$ & $\begin{array}{l}0.84 \pm \\
0.30\end{array}$ & $\begin{array}{l}52.01 \pm \\
0.95\end{array}$ \\
\hline I. Chicken Sausage & $\begin{array}{l}62.24 \pm \\
0.30\end{array}$ & $\begin{array}{l}8.16 \pm \\
0.96\end{array}$ & $\begin{array}{l}16.95 \pm \\
2.22\end{array}$ & $\begin{array}{l}2.21 \pm \\
0.10\end{array}$ & $\begin{array}{l}10.39 \pm \\
1.10\end{array}$ & $\begin{array}{l}4.09 \pm \\
0.37\end{array}$ & $\begin{array}{l}252.00 \pm \\
12.34\end{array}$ & $1.44 \pm 0.28$ & $\begin{array}{l}1.26 \pm \\
0.23\end{array}$ & $\begin{array}{l}43.63 \pm \\
3.84\end{array}$ \\
\hline J. Mutton Kabab & $\begin{array}{l}68.83 \pm \\
0.53\end{array}$ & $\begin{array}{l}7.56 \pm \\
0.53\end{array}$ & $\begin{array}{l}16.90 \pm \\
0.28\end{array}$ & $\begin{array}{l}2.18 \pm \\
0.10\end{array}$ & $\begin{array}{l}4.51 \pm \\
0.34\end{array}$ & $\begin{array}{l}1.56 \pm \\
0.16\end{array}$ & $\begin{array}{l}248.57 \pm \\
8.90\end{array}$ & $1.24 \pm 0.18$ & $\begin{array}{l}1.15 \pm \\
0.12\end{array}$ & $\begin{array}{l}60.72 \pm \\
0.98\end{array}$ \\
\hline L. Chicken Kabab & $\begin{array}{l}60.83 \pm \\
0.85\end{array}$ & $\begin{array}{l}10.79 \pm \\
0.28\end{array}$ & $\begin{array}{l}10.15 \pm \\
0.58\end{array}$ & $\begin{array}{l}2.63 \pm \\
0.09\end{array}$ & $\begin{array}{l}15.59 \pm \\
0.68\end{array}$ & $\begin{array}{l}2.72 \pm \\
0.32\end{array}$ & $\begin{array}{l}178.37 \pm \\
2.41\end{array}$ & $0.96 \pm 0.11$ & $\begin{array}{l}1.14 \pm \\
0.14\end{array}$ & $\begin{array}{l}46.42 \pm \\
3.40\end{array}$ \\
\hline M. Chicken Kabab & $\begin{array}{l}63.26 \pm \\
0.54\end{array}$ & $\begin{array}{l}11.54 \pm \\
0.21\end{array}$ & $\begin{array}{l}10.20 \pm \\
0.06\end{array}$ & $\begin{array}{l}2.37 \pm \\
0.00\end{array}$ & $\begin{array}{l}12.31 \pm \\
0.45\end{array}$ & $\begin{array}{l}2.19 \pm \\
0.09\end{array}$ & $\begin{array}{l}177.24 \pm \\
27.41\end{array}$ & $0.74 \pm 0.01$ & $\begin{array}{l}1.21 \pm \\
0.23\end{array}$ & $\begin{array}{l}52.44 \pm \\
5.65\end{array}$ \\
\hline N. Chicken Sausages & $\begin{array}{l}67.37 \pm \\
1.01\end{array}$ & $\begin{array}{l}10.59 \pm \\
0.18\end{array}$ & $\begin{array}{l}5.74 \pm \\
0.32\end{array}$ & $\begin{array}{l}2.41 \pm \\
0.00\end{array}$ & $\begin{array}{l}13.47 \pm \\
1.23\end{array}$ & $\begin{array}{l}2.02 \pm \\
0.03\end{array}$ & $\begin{array}{l}164.26 \pm \\
4.00\end{array}$ & $0.71 \pm 0.03$ & $\begin{array}{l}1.09 \pm \\
0.11\end{array}$ & $\begin{array}{l}33.54 \pm \\
1.54\end{array}$ \\
\hline
\end{tabular}

Table 7: Mineral profile of market meat products

\begin{tabular}{lllllll}
\hline Product & Calcium (\%) & Phosphorus (\%) & Cupper (ppm) & Zinc (ppm) & Manganese (ppm) & Iron (ppm) \\
\hline A. Chicken Kabab & $1.15 \pm 0.02$ & $0.57 \pm 0.02$ & $2.08 \pm 0.05$ & $21.87 \pm 0.17$ & $1.27 \pm 0.02$ & $56.89 \pm 0.12$ \\
C. Chicken Kabab & $1.63 \pm 0.03$ & $0.49 \pm 0.01$ & $1.03 \pm 0.02$ & $22.67 \pm 0.04$ & $2.55 \pm 0.03$ & $38.31 \pm 0.79$ \\
D. Chicken Kabab & $1.45 \pm 0.33$ & $0.61 \pm 0.01$ & $2.09 \pm 0.04$ & $14.32 \pm 0.01$ & $4.02 \pm 0.00$ & $51.32 \pm 0.48$ \\
F. Chicken Sausage & $1.61 \pm 0.00$ & $0.52 \pm 0.00$ & $1.76 \pm 0.01$ & $17.37 \pm 0.07$ & $5.42 \pm 0.14$ & $39.32 \pm 0.26$ \\
H. Chicken Kabab & $1.29 \pm 0.02$ & $0.68 \pm 0.00$ & $4.14 \pm 0.09$ & $22.92 \pm 1.14$ & $13.56 \pm 0.87$ & $99.82 \pm 0.84$ \\
I. Chicken Sausage & $1.43 \pm 0.03$ & $0.72 \pm 0.00$ & $2.31 \pm 0.10$ & $20.54 \pm 0.10$ & $9.07 \pm 0.08$ & $38.59 \pm 0.37$ \\
J. Mutton Kabab & $1.52 \pm 0.09$ & $0.76 \pm 0.01$ & $2.07 \pm 0.13$ & $22.01 \pm 0.95$ & $9.86 \pm 0.30$ & $83.72 \pm 2.31$ \\
L. Chicken Kabab & $1.40 \pm 0.09$ & $0.70 \pm 0.04$ & $0.90 \pm 0.32$ & $20.15 \pm 0.38$ & $8.24 \pm 0.08$ & $87.80 \pm 03.05$ \\
M. Chicken Kabab & $1.50 \pm 0.18$ & $0.76 \pm 0.09$ & $1.49 \pm 0.26$ & $18.61 \pm 0.71$ & $9.22 \pm 0.12$ & $78.09 \pm 0.56$ \\
N. Chicken Sausages & $1.55 \pm 0.17$ & $0.76 \pm 0.07$ & $1.47 \pm 0.32$ & $19.23 \pm 0.78$ & $9.48 \pm 0.37$ & $80.93 \pm 0.72$ \\
\hline
\end{tabular}

$(\mathrm{N}=10$, One sample from each shop).

oleic acid). The cholesterol content found maximum in J-Mutton Kabab sample (60.72 mg/100 g) and the lowest cholesterol concentration found in N-Chicken Sausages (33.54 mg/100g).

As far as mineral component is concern in the market samples, it has been found that the mineral content varied in samples (Table 7). The Calcium percentage found highest in Chicken Kabab from Shop-C (1.63\%), where as it was found lowest in Chicken Kabab from Shop-H (1.29\%). Market meat products found to be a good source of Iron, which was found in highest concentration in Chicken Kabab from Shop-H (99.82 ppm). 
Talukder et al.

Table 8: Microbial profile of market meat products

\begin{tabular}{llll}
\hline Product & Total Plate Count $(\log \mathbf{1 0} \mathbf{c f u} / \mathbf{g})$ & Psychrophilic Count $(\mathbf{l o g} \mathbf{1 0} \mathbf{c f u} / \mathbf{g})$ & Coliform Count $(\mathbf{l o g} 10 \mathrm{cfu} / \mathbf{g})$ \\
\hline A. Chicken Kabab & $4.97 \pm 0.04$ & $2.35 \pm 0.05$ & N.D. \\
C. Chicken Kabab & $3.75 \pm 0.10$ & $1.68 \pm 0.06$ & N.D. \\
D. Chicken Kabab & $5.41 \pm 0.16$ & $2.56 \pm 0.03$ & N.D. \\
F. Chicken Sausage & $5.17 \pm 0.08$ & $2.39 \pm 0.17$ & N.D. \\
H. Chicken Kabab & $3.15 \pm 0.10$ & $1.42 \pm 0.04$ & N.D. \\
I. Chicken Sausage & $4.46 \pm 0.19$ & $2.22 \pm 0.02$ & N.D. \\
J. Mutton Kabab & $4.35 \pm 0.28$ & $2.13 \pm 0.15$ & N.D. \\
L. Chicken Kabab & $4.39 \pm 0.22$ & $2.11 \pm 0.06$ & N.D. \\
M. Chicken Kabab & $3.10 \pm 0.07$ & $1.63 \pm 0.05$ & N.D. \\
N. Chicken Sausages & $4.26 \pm 0.15$ & $2.05 \pm 0.08$ & N.D. \\
\hline
\end{tabular}

$(\mathrm{N}=10$, N.D. $=$ Not Detected $)$.

The microbiological quality of meat products reflects the level of hygiene and cleanliness of production and processing practices adopted. The Total plate count (TPC) and psychrophilic count found in this study varied from sample to sample which is obviously due to the adoption of different processing and handling practices for meat product development (Table 8). The Coliform was not detected in the samples, which reflects the good hygienic practices during the processing.

Highest TPC as well as the Psychrophilic Count found in Chicken Kabab from Shop-D, $5.41 \mathrm{log} 10 \mathrm{cfu} / \mathrm{g}$ and $2.56 \mathrm{log}$ $10 \mathrm{cfu} / \mathrm{g}$ respectively. The high number of microorganisms, could be influenced due to many factors which affects the growth of microorganisms in meat products, these include handling of raw meat with contaminated hands, mixing of contaminated meat with other meat, improper cooking temperature and time schedule, adoption of unhygienic practices, use of contaminated water etc. Furthermore, the variations in TPC and psychrophilic count in different samples could be due to the materials and different treatment/processes used by the producers and sellers. This observation is in line with the findings of Igene et al. (2009).

\section{CONCLUSION}

In the present study meat consumption behaviour and the existing meat products quality in north Indian cities have been evaluated. It has been observed that, the choice of meat species by the consumers is being influenced by their gender, food habit, religion and their position in social stratum. According retailer there is a trend of increasing consumption of processed meat as compared to fresh meat. Both retailer and consumers revealed that the chicken is the most preferred meat species and Seekh Kabab is most preferred product. The preference of convenience meat products has been established in this study. The study showed a variation in quality of market meat products and the microbiological quality found satisfactory for most of the products. From the present study an idea can be obtained, about the thrust area where emphasis to be given to accelerate the pace of overall growth of Indian meat industry at present scenario.

\section{REFERENCES}

Anjaneyulu, A.S.R., Thomas, R., Gadekar, Y.P., Lakshmanan, V. and Mahapatra, C.M. 2008. Indian traditional meat products and their processing, quality, present scenario and future prospects. Ind. Food Ind., 27(2): 53-59.

AOAC. 1995. Official Method ofAnalysis. 16 Edn., Association of Official Analytical Chemists, Washington, DC.

APHA. 1984. Compendium of method for microbiological examination of food. 2 Edn., Speck, M.L. American Public Health Association, Washington DC.

Bhat, Z.F., Pathak, V. and Fayaz, H. 2013. Effect of refrigerated storage on the quality characteristics of microwave cooked chicken Seekh kababs extended with different non-meat proteins. J. Food Sci. Technol., 50(5): 926-933.

Chemnitz, C. and Becheva, S. 2014. Meat Atlas 2014. Retrieved 24 February 2014 from: www.foeeurope.org/meatatlas.

Devatkal, S.K., Manjunatha, M., Narsaiah, K. and Patil, R.T. 2014. Evaluation of quality characteristics of chicken meat 
emulsion/nuggets prepared by using different equipment. $J$. Food Sci. Technol., 51(3): 511-518.

Devi, S.M., Balachandar, V., Lee, S.I. and Kim, I.H. 2014. An outline of meat consumption in the indian population - A Pilot Review. Korean J. Food Sci. Anim. Resour., 34: 507-515.

FAO. 2012. World agriculture towards 2030/2050: the 2012 revision. Rome: ESA Working paper No. 12-03.

Furda, I. 1981. Simultaneous analysis of soluble and insoluble dietary fiber. In: The Analysis of Dietary Fiber in Food (W.P.T. James and O. Theander, Eds.). Marcel Dekker Inc., New York, pp. 163-172.

Gadekar, Y.P. and Shinde, A.K. 2011. Indian Meat Industry: Opportunities and Challenges. Ind. Food Indus., 30(4): 1722.

Guleria, P., Suman, K., Arshad, K. and Nidhi, D. 2015. Present Scenario of Indian Meat Industry-A Review. Int. J. Enhanced Res. Sci., Technol. Eng., 4: 251-257.

Haque, N. and Murari Lal. 1999. Gross energy estimation. In: Laboratory manual of animal nutrition. (V.R.B. Sastry, D.N. Kamra and N.N. Pathak, eds.), Indian Veterinary Research Institute, Izatnagar,UP, p. 71.

ICFA, 2016. www.icfa.org.in.

Igene, J.O., Farouk, M.M. and Akanbi, C. 2009. Preliminary studies on the quality and drying characteristics of "suya". Nigeria Food J., 7: 29-38.

Irshad, A. 2014. Development of low sodium, high dietary fibre functional restructured buffalo meat loaves fortified with calcium, vitamin C and E, M.V.Sc Thesis, ICAR-IVRI, Izatnagar.

Islam, M.M., Anjum, S., Modi, R.J. and Wadhwani, K.N. 2016. Scenario of livestock and poultry in india and their contribution to national economy. Int. J. Sci. Env. Technol., 5: $956-965$

Jalal, H., Para, P.A., Bhat, M.M., Bukhari, S.A., Ganguly, S., Padhy, A., Wakchaure, R., Praveen, P.K. and Qadri, K. 2015. Low fat meat products in consumer demand: a review. World J. Eng. Res. Technol., 1(2): 22-25.

Koniecko, E.K. 1979. Handbook for Meat Chemists. Avery PublishingGroup Inc., Wayne, New Jersey, USA, pp. 68-69.
Malav, O.P., Sharma, B.D., Kumar, R.R., Talukder, S., Ahmed, S.R. and Irshad, A. 2016. Quality characteristics and storage stability of functional mutton patties incorporated with red kidney bean powder. Ind. J. Small Rumin., 22(1): 83-91.

Mohanty, B.P. 2011. Fish as Health Food. In: Handbook of Fisheries and Aquaculture, $2^{\text {nd }}$ edn Ch. 35, pp. 843-861. ICAR - DKMA, New Delhi.

Prattala, R., Paalanen, L., Grinberga, D., Helasoja, V., Kasmel, A. and Petkeviciene, J. 2006. Gender differences in the consumption of meat, fruit and vegetables are similar in Finland and the Baltic countries. Eur. J. Pub. Health, 17(5): $520-525$.

Raju, D.T. and Suryanarayana, M.V.A.N. 2005. Meat consumption in Prakasam district of Andhra Pradesh: an analysis. Livest. Res. Rural Dev., 17(11): 1-9.

Sharma, N. 2003. Health and muscle foods. In: 5th International food convention on "Innovative Food Technologies and Quality systems strategies for Global competitiveness". CFTRI, Mysore, 183-184.

Sharma, S., Pathak, V., Singh, V. P., Awasthi, M. and Bharti, S. 2018. Comparative quality assessment of meat nuggets prepared from meat of different food animals. Int. J. Livest. Res., 8(1): 139-148.

Talukder, S. and Mendiratta, S. 2017. Exploring purple leaf sandcherry (Prunus cistena) extracts based indicator to monitor meat quality during storage at $10 \pm 1^{\circ} \mathrm{C}$. Int. J. Livest. Res., 7(8): 214-220.

Tarladgis, B.G., Watts, B.M., Yaunathan, M.T. and Dugan, L.R. 1960. Distillation methods for the quantitative determination of malonaldehyde in rancid foods. J. Ame. Oil Chem. Soc., 37: 66-71.

Tzimitra-Kalogianni, I. 1998. Consumer's attitudes to frozen meat. MEDIT, 96(3): 34-37.

Vijayabaskar, M. and Sundaram, M. 2012. A market study on key determinants of ready-to eat/cook products with respect to tier-i cities in southern India. Int. J. Multidis. Res., 2(6): 168-180. 
